\title{
Prevalence of antibody to human $T$ lymphotropic virus type III by risk group and area, United Kingdom 1978-84
}

\author{
P P MORTIMER, W J JESSON, E M VANDERVELDE, M S PEREIRA
}

\begin{abstract}
Antibody to human T lymphotropic virus type III (anti-HTLV-III) was sought in 2150 patients in three groups at risk with a radioimmunoassay and an immunofluorescence test. Results by the two methods were closely concordant. Anti-HTLV-UI was already present in some British homosexuals in 1980 and in some British haemophiliacs in 1981 , and since then its prevalence has increased. Of homosexual patients needing laboratory tests for hepatitis $B$ virus infection in 1984, 34\% of 282 in London and $5 \%$ of 955 in five centres outside London were positive for anti-HTLV-III. Of haemophiliacs sampled in $1984,38 \%$ of 81 were antiHTLV-III positive. Most of the seropositive haemophiliacs were regular recipients of commercial factor VIII concentrates. Few British intravenous drug abusers sampled in $1984(2.5 \%$ of 203$)$ were positive for antiHTLV-III. These results show that infection with HTLVIII has rapidly become widespread among homosexuals attending sexually transmitted disease clinics and among haemophiliacs receiving pooled blood products.

Thus, while many anti-HTLV-III positive individuals may remain asymptomatic, there may soon be a considerable increase in the incidence of the acquired immune deficiency syndrome and related disease in Britain.
\end{abstract}

\section{Introduction}

The acquired immunodeficiency syndrome (AIDS) is a recently recognised infectious disease that is now prevalent in several American and European cities. By the end of November 1984 some 6993 American and at least 580 European cases, including 102 British ones, had been reported (Centers for Disease Control, Atlanta, AIDS Activity Weekly Report; WHO Collaborating Centre on AIDS, Paris; PHLS Communicable Disease Surveillance Centre, London; all unpublished). AIDS is usually transmitted by sexual intercourse but can also spread through blood and blood products. Cases have occurred mostly in homosexual men, but also in haemophiliacs, intravenous drug abusers, and recipients of blood transfusions.

AIDS is probably caused by a single, rather heterogeneous virus. This was first described as lymphadenopathy associated virus $^{1}$ and then as human $T$ lymphotropic virus type III (HTLV-III). ${ }^{2}$ The virus probably acts by progressively depleting the T4 "helper" lymphocyte population through persistent infection. ${ }^{3}$ While some patients infected with HTLVIII develop AIDS - that is, frank immunodeficiency with opportunistic infections and malignancies-more have features

\footnotetext{
Virus Reference Laboratory, Central Public Health Laboratory, London NW9 5HT

P P MORTIMER, MD, MRCPATH, consultant medical microbiologist W J JESSON, MB, MRCPATH, assistant medical microbiologist E M VANDERVELDE, MB, DIPBACT, senior medical microbiologist M S PEREIRA, MD, director

Correspondence to: Dr P P Mortimer.
}

such as fever, fatigue, weight loss, diarrhoea, and lymphadenopathy (the AIDS related complex) without having developed opportunistic infections. Many other individuals in groups at risk are asymptomatically infected with HTLV-III. ${ }^{4-6}$

Tests for antibody to HTLV-III can be used to identify individuals who have been infected and to gauge the prevalence of infection in sample populations. When the prognosis for seropositive people is better understood the results of these surveys will allow future disease patterns and requirements for medical care to be predicted. In this study samples collected from 1978 to 1984 from three British groups at risk were tested for anti-HTLV-III: male homosexuals, haemophiliacs, and intravenous drug abusers.

\section{Methods}

Sera from homosexuals were obtained from a bank of specimens in the PHLS Virus Reference Laboratory, London, and from similar stores of sera in public health laboratories in five widely distributed provincial centres (A to E). Most of these sera, and sera from patients with haemophilia and from drug abusers, had been collected for routine diagnostic tests of hepatitis $B$ virus infection. The exceptions were, firstly, sera from centres $A$ and $E$ and sera from 12 patients with AIDS, which were taken from sexually active homosexuals and submitted specifically for HTLV-III testing, and, secondly, specimens from blood donors (collected in London in May 1982), from people vaccinated against hepatitis $B$ virus, and from therapeutically immunosuppressed patients. This second group of specimens was used only to investigate the specificity and sensitivity of the assays.

The two tests used to detect anti-HTLV-III were based on continuous lines of HTLV-III infected lymphocytes (HT/H9/3) and uninfected lymphocytes (HT/H9), both generously given by Dr R C Gallo. The cells were grown in suspension in plastic flasks on RPMI medium with $10^{\circ}$, fetal calf serum.

Antigen for radioimmunoassay was prepared by freezing and thawing a resuspended pellet of $\mathrm{HT} / \mathrm{H} 9 / 3$ cells and treating the slurry successively with $0 \cdot 25^{\circ}$, 3 propiolactone and $0 \cdot 1^{\circ}$, Tween 20 . Immunoglobulin $G$ was prepared on DE 52 ion exchange resin from a serum, F, with a high anti-HTLV-III titre. Polystyrene beads $6 \mathrm{~mm}$ in diameter were coated with $\mathrm{IgG}-\mathrm{F}$, washed, and immersed in the antigen until used. IgG-F was also radiolabelled with iodine125. Anti-HTLV-III was detected by a competitive radioimmunoassay $^{6}$ in which a mixture of $20 \mu \mathrm{l}$ of each serum and $180 \mu \mathrm{l}$ of ${ }^{125} \mathrm{I}-\mathrm{IgG}-\mathrm{F}$ (diluted to $10^{5} \mathrm{cpm}$ ) was incubated overnight with an antigen coated bead. In this assay a 1/200 dilution of serum $F$ in anti-HTLV-III negative control serum inhibited about $80 \%$ and a $1 / 1000$ dilution about $60^{\prime \prime}$ " of the ${ }^{125} \mathrm{I}-\mathrm{IgG}-\mathrm{F}$ binding that occurred in the presence of the negative control serum. On this basis, the reactions of test specimens were divided into strongly positive $\left(-80 \%\right.$ inhibition), weakly positive $\left(60^{\circ},-80 \%\right.$ inhibition), and negative.

For the immunofluorescence test $\mathrm{HT} / \mathrm{H} 9 / 3$ and $\mathrm{HT} / \mathrm{H} 9$ cells were gently centrifuged and the deposit resuspended in phosphate buffered saline. Ten $\mu l$ volumes were applied to coverslips, dried in air, fixed in acetone for 10 minutes and exposed to ultraviolet light for 20 minutes. The coverslips were stored at $-20 \mathrm{C}$ until used. Sera were inactivated at $56^{\circ} \mathrm{C}$ for 30 minutes and applied, at a dilution of $1 / 8$, to the cell preparations. After one hour at $37 \mathrm{C}$ in a moist chamber and three 10 minute washes in phosphate buffered saline the coverslips were dried and $10 \mu \mathrm{l}$ of fluorescein conjugated antihuman IgG applied to each preparation. After further incubation for one hour and three 10 minute washes, the coverslips were dried, fixed to microscope slides with polyvinyl alcohol, and examined microscopically in ultraviolet light. Anti-HTLV-III positive and negative control sera were included in each batch of tests. Sera that 
gave rise to fluorescence in $\mathrm{HT} / \mathrm{H} 9 / 3$ but not in $\mathrm{HT} / \mathrm{H} 9$ cells were scored as strongly or weakly positive according to brightness. Fluorescence did not occur in $\mathrm{HT}$ H9 cells.

\section{Results}

Assessment of radioimmunoassay and immunofluorescence tests for anti-HTLV-III-Fifty out of 50 blood donations, 50 out of 50 immunosuppressed patients, and 23 out of 23 recipients of hepatitis $B$ virus vaccine sampled three to six months after the third dose of vaccine were anti-HTLV-III negative by radioimmunoassay. Twelve out of 12 patients with AIDS were anti-HTLV-III positive by radioimmunoassay and by the immunofluorescence test. The first 192 sera examined that were negative by radioimmunoassay were all negative by immunofluorescence testing and, thereafter, only sera positive by radioimmunoassay were tested by immunofluorescence. Four out of 273 of these sera positive by radioimmunoassay were negative by immunofluorescence testing (table I).

Homosexual patients-In London sera from homosexuals attending clinics for sexually transmitted diseases were tested. The proportion who were anti-HTLV-III positive rose steadily from 1980 to 1984 , and in 1984 a third of those sampled were positive (table II). Outside London sera collected, mostly during 1984, from homosexual patients at clinics in five provincial centres were tested. The prevalence of anti-HTLV-III ranged from $1 \cdot 6^{\circ}{ }_{0}$ to $11 \cdot 2^{\circ}{ }_{0}$ and was $5 \cdot 1 \%$ overall (table III)

TABLE I-Comparison of competitive radioimmunoassay and immunofluorescence for measuring anti-HTLV-III

\begin{tabular}{lcccc}
\hline & \multicolumn{4}{c}{ Radioimmunoassay } \\
Immunofluorescence & Strong positive $(>80)^{*}$ & Weak positive $(60-80)^{*}$ & Negative \\
\cline { 2 - 5 } & 246 & 3 & 0 \\
Strong positive & 13 & 7 & 0 \\
Weak positive & 1 & 3 & 192 \\
Negative & & &
\end{tabular}

*Percentage inhibition of $1: \mathrm{I} \mathrm{I}-\mathrm{IgG}-\mathrm{F}$ binding.

TABLE II-Prevalence of anti-HTLV-III in homosexual patients in London

\begin{tabular}{llllll}
\hline \multicolumn{1}{c}{ Year: } & 1980 & 1981 & 1982 & 1983 & 1984 \\
\hline $\begin{array}{l}\text { No tested } \\
\begin{array}{l}\text { No (") anti-HTLV-III } \\
\text { positive (radioimmuno- } \\
\text { assay) }\end{array}\end{array}$ & 95 & 130 & 197 & 156 & 126 \\
& $5(5 \cdot 2)$ & $9(6 \cdot 9)$ & $22(11 \cdot 2)$ & $31(19 \cdot 9)$ & $43(34 \cdot 1)$
\end{tabular}

TABLE III-Prevalence of anti-HTLV-III in homosexual patients outside London in 1984

\begin{tabular}{lllllll}
\multicolumn{1}{c}{ Centre: } & A & B & C & D & E & Total \\
\hline $\begin{array}{l}\text { No tested } \\
\text { No (") anti-HTLV- } \\
\text { III positive } \\
\text { (radio- } \\
\text { immunoassay) }\end{array}$ & 513 & 40 & $151^{*}$ & 299 & 152 & 955 \\
\hline
\end{tabular}

*Includes 77 serum samples from 1983

Patients with haemophilia-Sera collected at one treatment centre from 1978 to 1981 and at several others since 1980 were tested. From most patients only single samples were available, but from others there were several samples collected over several years. From the first centre 302 sera from 111 patients were tested, and only two patients, both sampled in 1981, were positive for anti-HTLV-III. From the other centres 223 sera from 177 patients were tested, and 55 patients were positive for anti-HTLV-III. Thirteen patients who had antibody in sera taken in 1983 or 1984 had no antibody in sera taken before 1983 . From the remaining 42 positive patients only single samples were available. Of these positive samples, four were collected in 1982, seven in 1983, and 31 in 1984. Most of the patients positive for anti-HTLV-III (21 out of 31 in 1984) were known to be receiving regular commercial factor VIII concentrate.
Drug abusers-Sera from 203 intravenous drug abusers from all over England were examined. Most had a clinical diagnosis of acute viral hepatitis and 152 had hepatitis B surface antigen ( $\mathrm{HBsAg}$ ) in their serum. Five $(2.5 \%)$, including three who were positive for HBsAg, were also positive for HTLV-III.

\section{Discussion}

Though it cannot be assumed that all individuals infected with HTLV-III have antibody to it, the need for convenient, sensitive, and specific tests for anti-HTLV-III is indisputable. The competitive radioimmunoassay, a one step multiwell method, as well as being suitable for large seroepidemiological surveys, has been extensively used in assays for antibodies to hepatitis and herpes viruses ${ }^{7-9}$ and has proved both specific and sensitive. Our results and those of others ${ }^{6}$ on blood donors and other groups indicate that it is a specific method for antiHTLV-III, and this may be an advantage over the enzyme assays now under development, in which it has been suggested that many false positive reactions may occur. ${ }^{10}$ The competitive radioimmunoassay for anti-HTLV-III is also adequately sensitive. A whole virus antigen capable of detecting a broad spectrum of antibodies is used, and almost all patients with AIDS have anti-HTLV-III detectable by it. ${ }^{6}$ The immunofluorescence test used in this study was based on acetone fixed cells and approached the radioimmunoassay in sensitivity. In both procedures steps were taken ( $\beta$ propiolactone and detergent treatment, acetone, and ultraviolet irradiation) that are thought to inactivate HTLV-III. These steps and the heat inactivation of serum specimens are likely to be important in rendering methods for anti-HTLV-III testing safe. The radioimmunoassay and immunofluorescence tests will also be convenient alternatives to the cumbersome "Western" blot procedure for verifying positive results arising in the forthcoming commercial enzyme assays for anti-HTLV-III.

Our results show that since 1980 HTLV-III infection has become well established among British homosexuals attending sexually transmitted disease clinics. Most of the patients sampled were originally investigated for hepatitis B infection and, as the risk of this correlates with promiscuity, ${ }^{11}$ this implies that they were more sexually active than other homosexuals. Among clinic patients, however, they were probably not a highly selected group. The prevalences of antiHTLV-III in patients from the two centres $A$ and $E$, where all homosexual patients attending clinics were sampled over about three months in 1984 , were respectively the lowest and the highest in provincial centres. This suggests that confining testing in the other centres to samples taken to diagnose hepatitis $B$ virus did not lead to a distorted picture of the prevalence of anti-HTLV-III in homosexuals attending sexually transmitted disease clinics.

Our data on British haemophiliacs show that, though infection may have appeared somewhat later, their prevalence of antiHTLV-III is now higher than that of sexually active homosexuals. Moreover, the general antibody prevalence found in British haemophiliacs conceals a prevalence above $50 \%$ in patients who have regularly received imported factor VIII concentrates (Moffat EH, et al, submitted for publication). Most seroconversions occurred in 1983 and 1984, and it is reasonable to suppose that the American factor VIII concentrate was mainly responsible. More American than domestic concentrate is used in Britain, and the higher incidence of AIDS and AIDS related disease in the United States implies that HTLV-III infection is more prevalent in the American than the British blood donor population. Concentrates are made from pools of many thousand donations and a single HTLV-III infected unit can probably contaminate an entire batch. Eventually the risk of infection will be diminished by screening all blood donations for anti-HTLV-III and heating concentrates to destroy the virus. In the meantime seronegative haemophiliacs must be identified and treated with heated concentrates. 
The survey of British drug abusers, carried out on 1984 sera, shows that the prevalence of anti-HTLV-III already noted in this group remains low, ${ }^{6}$ even in a selected group whose main underlying disease, hepatitis $\mathrm{B}$, implies intravenous administration of drugs and therefore an increased likelihood of blood borne infection. Nevertheless, a recent study of drug abusers in New York showed $87 \%$ to be infected, ${ }^{5}$ and HTLVIII infection might readily spread among intravenous drug abusers here, just as other viruses such as hepatitis B virus and hepatitis $\mathrm{D}$ virus ( $\delta$ agent) have done. ${ }^{12}$ In Central Africa, where AIDS is common and increasing in incidence, heterosexual intercourse seems to be the main mode of spread of HTLV-III. ${ }^{13}$ In Britain, drug abusers and haemophiliacs are two groups from which it is possible that HTLV-III infection may spread by this route.

This is the second seroepidemiological survey of HTLV-III infection in Britain. It confirms the results of the first ${ }^{6}$ and extends them in two respects: it shows that the infection has become increasingly widespread since 1980-1 in the two groups mainly affected and that HTLV-III has become prevalent in homosexuals throughout the country. The prevalence of anti-HTLV-III in the provinces is likely to increase as it has done in London, and further spread of infection can be avoided only by homosexuals very strictly limiting the numbers of sexual partners and preventing the transfer of semen. These are measures that must be urged on individuals, both through homosexual support groups and through adequate counselling services. Similarly, the potential for further spread of infection among haemophiliacs, other blood recipients, and drug abusers is a pressing problem demanding new resources to support prophylactic measures.

Because the epidemiological factors may change it is impossible to predict how many cases of AIDS there will be in Britain in the next few years. Though at first sight the outbreak is small and circumscribed, there is a constant upward trend and no signs of a plateau in the rate of increase of cases reported (M McEvoy, personal communication). Few of the seropositive individuals identified in this study are known or thought to have developed AIDS related disease, and the extent of HTLVIII infection in Britain shown by the results of two large seroepidemiological studies is not reflected in the current, uncommon occurrence of AIDS and the AIDS related complex. Nevertheless, infection can continue to spread from seropositive individuals, ${ }^{1+}$ and attempts to control this certainly cannot await the remote prospect of a vaccine. The virus seems to be transmitted only by the inoculation of blood, semen, and possibly saliva. ${ }^{16}$ Every effort must therefore be made by the individuals at immediate risk and those concerned in their medical care to prevent these transmission events.

The needs of seropositive individuals, an unknown proportion of whom will develop AIDS related illness, must also be considered. The finding that some British patients were seropositive as long ago as 1980 should prompt investigation of their long term health. These studies, though difficult to mount, will be very important in planning for future care. At present there is insufficient provision for the advice and treatment of HTLV-III infected patients. The evidence from seroepidemiological surveys and continuing laboratory investigations of the HTLV-III epidemic point to a need for a rapid, adequate, and humane response to the predicament of those who have and will become infected.

We thank Professor R A Weiss and Dr R S Tedder for their advice and for the gift of serum $F$, and the many people who sent serum samples. Important contributions were made by $\mathrm{Dr} A$ Aronstam, Dr T D L Davies, Dr H S Holzel, Dr F E Preston, Dr T R Rogers, and Dr D C Shanson; also by collaborating staff of the Public Health Laboratory Service, including Dr B W Barton, Dr A A Codd, Dr B J Cohen, Dr S D Gardner, Dr J Gray, Dr M H Hambling, Dr S Polakoff, Dr B T Thom, and Dr G C Turner.

\section{References}

1 Barré-Sinoussi F, Chermann JC, Rey F, et al. Isolation of a T lymphotropic retrovirus from a patient at risk for acquired immune deficiency syndrome (AIDS). Science 1983;220:868-70

2 Gallo RC, Salahuddin SZ, Popovic M, et al. Human T-lymphotropic retrovirus, HTLV-III, isolated from AIDS patients and donors at risk for AIDS. Science $1984 ; 224: 500-3$.

3 Klatzmann D, Barré Sinoussi F, Nugeyre MT, et al. Selective tropism of lymphadenopathy associated virus (LAV) for helper-inducer T lymphocytes. Science $1984 ; 225: 59-63$

4 Safai B, Sarngadharan MG, Groopman JE, et al. Seroepidemiological studies of human T-lymphotropic retrovirus type III in acquired immunodeficiency

Centers for Disease Control. Antibodies to retrovirus etiologically associated with acquired immunodeficiency syndrome (AIDS) in populations with increased incidences of the syndrome. $M M W R$ 1984;33:377-9.

6 Cheingsong-Popov R, Weiss RA, Dalgleish A, et al. Prevalence of antibody to human T-lymphotropic virus type III in AIDS and AIDS-risk patients in Britain. Lancet 1984;ii:477-80

7 Flehmig B, Zahn J, Vallbracht A. Levels of neutralizing and binding antibodies to hepatitis-A virus after onset of icterus: a comparison. $\mathcal{F}$ Infect Dis 1984; $150: 461$.

8 Cohen BJ, Litton PA, Mortimer PP, Simmons P. Hepatitis B core antigen synthesised in Escherichia coli: its use for antibody screening in patients attending

9 Tedder RS, Mortimer PP, Lord BR. Detection of antibody to varicella-zoster virus by competitive and IgM-antibody capture immunoassay. I Med Virol 1981;8:89-101.

10 Goldsmith MF. HTLV III testing of donor blood imminent: complex issues remain. FAMA 1985;253:173-81

$11 \mathrm{Lim}$ KS, Taam Wong V, Fulford KWM, et al. Role of sexual and non-sexual practices in the transmission of hepatitis B. Br f Vener Dis 1977;53:190-2.

12 Shattock AG, Kelly MG, Fielding J, Arthurs Y. Epidemic hepatitis B with delta anti $334-8$.

13 Brun-Vézinet F, Rouzioux C, Montagnier L, et al. Prevalence of antibodies to lymphadenopathy associated retrovirus in African patients with AIDS. Science $1984: 22: 453-6$

14 Groopman JE, Salahuddin SZ, Sarngadharan MG, et al. HTLV-III in saliva of people with AIDS-related complex and healthy homosexual men at risk for AIDS. Science 1984;226:447-9.

15 Hirsch MS, Wormser GP, Schooley RT, et al. Risk of nosocomial infection with human T-cell lymphotropic virus III (HTLV III). N Engl f Med 1984;
312:1-4.

(Accepted 18 February 1985)
Fenclofenac is a phenylacetic acid derived non-steroidal antiinflammatory drug which has been in wide use for about eight years. Side effects are similar to those of other non-steroidal anti-inflammatory agents and have included a diminution of renal function and occasional proteinuria. Allergic interstitial nephritis has been frequently reported after treatment with propionic acid derivatives such as fenoprofen. ${ }^{12}$ There have been only two reports of this complication after fenclofenac, however, and on each occasion additional drugs had been prescribed. We have recently seen a case of biopsy proved allergic interstitial nephritis associated with fenclofenac which recurred when the patient was inadvertently rechallenged with the drug.

\section{Case report}

A 65 year old man developed acute oliguric renal failure while on holiday in Israel. The oliguria was associated with arthralgia and an erythematous rash. The patient admitted ingestion of Enterosan (a proprictary antidiarrhoeal preparation) but denied use of any other drugs.

Investigation disclosed plasma creatinine concentration of $1045 \mu \mathrm{mol} 1(11.8 \mathrm{mg} / 100 \mathrm{ml})$, and an absolute eosinophil count of $1.6 \times 10^{9} / 1$. Intermittent haemodialysis was begun 